\title{
THE CORRELATION BETWEEN STUDENT'S HABIT IN WATCHING ENGLISH MOVIE AND VOCABULARY MASTERY AT THE SECOND YEAR OF SMAN 1 ANGGERAJA
}

\author{
Dahniar \\ Masyhud Zainuddin \\ Universitas Islam Negeri Alauddin Makassar \\ badruddindabniar01@yahoo.com \\ masybudz@yahoo.co.id
}

\begin{abstract}
The objective of this research was to find out whether there is a correlation between students' habit in watching English movie and vocabulary mastery at the second year of SMAN 1 Anggeraja in the academic year 2015/2016. This study is a correlation research. The instruments used were questionnaire and vocabulary test. The result of the analysis showed that there was significant correlation between students' habit and vocabulary mastery in watching English movie to 0.766 at the significant level of 0.05 with the critical value of $r$ table 0.339 . The correlation between students' habit in watching English movie and vocabulary mastery was significant since the coefficient correlation is higher than the critical value of $\mathrm{r}$ table $(0.766>0.339)$. It means that there is a significant correlation between students' habit in watching English Movie and Vocabulary Mastery at the Second Year of SMAN 1 Anggeraja.
\end{abstract}

KEYWORDS: habit, English movie, vocabulary

\section{A. INTRODUCTION}

$\mathrm{V}$

ocabulary is the total number of words, which makes up the language. It can be defined as the word we teach in the foreign language. Studying language can be started by learning vocabulary first. It is the most important element of language.

Vocabulary is the central of language and it is important to the language students. Without mastering the vocabulary, students cannot communicate effectively and express their ideas in both oral and written form in order to discovering the meaning of what others say. Most of students have problem in mastering vocabulary, including students in SMAN 1 Anggeraja. They face many problems in learning English. The lack of students' vocabulary mastery may come from both the students as the students; their laziness in memorizing a number of words required, the lack of interest and motivation in learning English, or even the students' health condition, and the teacher as the instructor to solve this problem. Of course, in this case, the creativity of a teacher in choosing a technique is needed. In other words, a teacher should have more attention to techniques in improving the students' vocabulary mastery.

Furthermore, the hypothesis of this research was "there is a significant correlation between students' habit in watching English movie and vocabulary mastery at the second year of SMAM 1 Anggeraja". To solve the problem stated previously, the researcher utilized 
visual strategy namely watching English movie. The researcher measured the score of student's habit first. Then, the students were given vocabulary test to know their vocabulary mastery. The researcher eventually found the positive correlation between students' habit and vocabulary mastery. The result can be recommended to the teacher as a media of teaching vocabulary. Habit in watching English movie provides opportunities to study language about vocabulary. Moreover, students should have a schedule for it in order they can get new vocabularies and find many information about structure, difficult new vocabulary based on the dialogue by the native speaker. Then, they can look for the solution of the problems by asking to the teacher or looking for the other referent. Indirectly, students will study about English vocabulary by watching movie.

\section{B. LITERATURE REVIEW}

A number of studies had been conducted in order to investigate the correlation between students" habit in watching English movie and vocabulary mastery. First, Ahmad Syafi'i (2013), conducted a research under the title "Korelasi antara Kebiasaan Menonton Film Berbahasa Inggris dan Pengusaan Kosa Kata Siswa di SMKN 1 Salatiga". The result has shown that there was a significant correlation between students' habit in watching English movie and vocabulary mastery with correlation coefficient $r=0.790, p(0.01)$. It means that, the higher students' habit in watching English movie, the higher students' vocabulary mastery.

Furthermore, Arif Rahman (2012), conducted a research under the title "Correlation between Frequency of Watching English Movies and Vocabulary Mastery of the Second Grade Students of MAN 1 Semarang in the Academic Year of 2011/2012”. The result has shown that there was a significant correlation between frequency of watching English movies and vocabulary mastery. It was proven by the result of $\mathrm{r}$ of product moment coefficient value that is higher than $\mathrm{r}$ of table coefficient value. So, he concluded that the frequency of watching English movie can give effect to the vocabulary mastery.

It can be concluded that strength of students' habit in watching English movie has correlation with vocabulary mastery. Some factors that can influence the vocabulary mastery of the students are learning material or technique presented in the class. Some kinds of learning material and teaching technique described above are proven to be effective to increase the vocabulary mastery of the students.

\section{Habit}

This section presented about the habit, habitual learning, and learning strategies.

a. Habit definition

A habit, from the standpoint of psychology, is a more or less fixed way of thinking, willing, or feeling acquired through previous repetition of a mental experience, (Andrews, 1903). 
Dahniar \& Masyhud Zainuddin, The Correlation Between Student's Habit in Watching English Movie. . .

b. Habitual Learning

In psychology, habituation is an example of non-associative learning in which there is progressive diminution of behavioral response probability with repetition of a stimulus. It is another form of integration (www.suite101.com). It is concluding that habitual learning is the learning by using repetition in a way of learning. The learners do something continuously and repeatedly and this activity is used as a way in learning something to improve their achievement. In short, habitually learning by using habit. Some Indonesian students probably like to use their habits in watching movie to enrich their vocabulary, grammar, pronunciation, spelling, etc.

c. Learning strategies

Learning strategies are specific action taken by the learner to make learning easier, faster, more directed, more effective. In this study watching movie habit is learning strategy. Learning strategies of vocabulary divide into two strategies, they are conventional strategy and visual strategy, (Diana Thomas, 1995:26).

\section{English Movie}

a. Movie Definition

A film, also called a movie or motion picture, is a series of still or moving images. It is produced by recording photographic images with cameras, or by creating images using animation techniques or visual effect (Wikipedia.com). Furthermore, Bong S Eliab (2015) stated that analyzing movie the first thing is to understand the elements of movie. They are story, character, theme, setting, and style.

b. Advantages and disadvantages of movie

There are many advantages that can be obtained in the use of film as a media to deliver lessons to the students. They are:

1. Movie can be describe process.

2. Movie can arouse impression of room and time.

3. The pictures are three dimensions.

4. The sound can arouse reality of pictures in form of nature expression.

5. Movie can tell expert's voice while watching his/ her appearance.

6. Color movie can add reality of object, which is practiced.

7. Movie can show scientific theory and animation.

Beside the advantages, movie has disadvantages that can be explained as follow:

1. During playing movie, teachers cannot explain any material because it can disturb students' concentration.

2. Students cannot understand the movie well if it is played too fast.

3. It is difficult to repeat what is gone except playing it once more.

4. The equipment is expensive. 
A good film is a film that can meet the needs of students in relation to what has been learned. Oemar Hamalik argues that adhere to basic principles of 4- $\mathrm{R}$ is: "the right film is the right place at the right time used in the right way".

Vocabulary

a. Vocabulary Definition

Good (1973:624) defines vocabulary as content and function words of language which are learned so thoroughly so that become part of child's understanding, speaking, and later reading and writing vocabulary.

b. Kinds of Vocabulary

Karim (2000) divides vocabulary into four parts, they are:

1. Active Vocabulary

Numbers of words that are used by an individual as opposed to number she/he is able to understand.

2. Basic Vocabulary

Words and idiomatic expression is necessary for minimal use and working knowledge of a language.

3. Passive Vocabulary

Numbers of words understood by child as opposed to the number of words used.

4. Vocabulary Growth

Development of vocabulary with age, the speed of development depends on intellect and linguistic environment.

c. Technique of learning vocabulary

Harmer (1991) describes some ways in presenting vocabulary, as follows:

1. Realia

This way, the teacher brings the real object into the classroom and introduced to the students.

2. Pictures

Teaching vocabulary through pictures is familiarly focuses on the object.

3. Mime, action, and gesture

It is often impossible to explain the meaning of words and grammar either through the use of realia or in pictures. Action, in particular, are probably better explained by mime (concept like running and smoking are easy to present in this way).

4. Contrast

This way, the teacher shows the students a word and asks the students to find out the contrast of the word. 
Dahniar \& Masyhud Zainuddin, The Correlation Between Student's Habit in Watching English Movie. . .

5. Enumeration

This way requires the teacher to introduce words by enumeration them with their general and specific meaning.

6. Explanation

This way, the teacher introduces words by explaining or describing the objects and asks the students to guest what the object is.

7. Translation

This way, the teacher asks the students to translate the given words into their mother tongue (native language).

d. Technique of teaching vocabulary

Ruth Gaims and Stuart Redman (2003), they mention two technique if teaching vocabulary. There are visual technique and verbal technique.

1. Visual technique

a. Mime and gestures

In this technique, the teacher can use real object and command. In real object, the teacher can use something available in the classroom such as door, whiteboard, board marker, clock, and so on. In using command, a teacher can give command such as open the window; open your book, etc.

b. Visual aids

In this technique, the teacher can use pictures, photographs, flashcards, and whiteboards as the visual aid. One of the visual aids that possibly used is whiteboards. The picture for vocabulary teaching come from many sources. It can be from the magazine, newspaper, or the student's handmade.

2. Verbal technique

a. Use of illustrative situations (oral or written)

This technique can be useful when the words are abstract. In this technique teachers just explain the word so that teachers should use more than one situation or context to ensure that students understand what they explained.

b. The use of synonym and definition

Synonym can be called the words that have similar meaning with other words. Teachers often use this technique to low level students; it would be justifiable at low levels to tell students that miserable mean very sad. Secondly, it is commonly used with higher level students and subsequently qualified, such as Male means man.

c. Contrast and opposites

In this technique, the teacher asks the students the opposite of something, for example, what is the opposite of sweet? What is the opposite of clever? etc. 
d. Scales

It can be useful way to get new vocabulary if students have learned contrasting or related gradable items. If students know 'hot' and 'cold' teachers can ask students a framework for feeding in 'warm' and 'cool' and later 'freezing' and 'boiling'.

e. Example

The teachers can use illustration to get the meaning of subordinates, such furniture, vegetables, and fruits. It is a common produce to exemplify them e.g. table, chair, and bed are all furniture.

e. Teaching vocabulary by using movie in Senior High School

Teachers can start learning English from simple way by using visual media such as newspaper, flash card, and magazine. But teaching by using movie is more interesting and it can make students easier to understand what the point of that movie is. To teach vocabulary by means of movie, the teachers have to use media efficiently to make media become more effective and make students feel enjoy and comfort.

\section{RESEARCH METHOD}

The researcher conducted a Correlation Research with using quantitative data approach. Population in in this research were the second year students of SMAN 1 Anggeraja on Social Program in the academic year 2015/2016, amounting 140 students. The researcher took 34 students of XI IPS 3sample is all by using purposive sampling. The instrument of this research used questionnaire and vocabulary test. The questionnaire was used to know the score of student's habit. The vocabulary test was used to know the score of student's vocabulary mastery.

Furthermore, the procedure of the research was presented as the following:

First, the researcher distributed the questionnaire about the habit of watching English movie totaling 10 questions in the form of multiple choice with choice of A, B, C, D, and E. The questionnaire used the score between 1 till 5. So, each answer choice was meant to symbolize the difference the levels habit of to watch English movie of the students. Second, after answering the questionnaire, the researcher took it back. After that, to measure the student's vocabulary mastery, the researcher gave opportunity to the students watching an English movie titled Madagascar 4. Third, while watching, students paid close attention conversations on the movie so that students can answer the vocabulary mastery test later on. Finally, after watching the movie, the researcher distributed the vocabulary mastery test to measure the student's vocabulary mastery. After answering the test, the researcher collected all the tests from the students. 
Dahniar \& Masyhud Zainuddin, The Correlation Between Student's Habit in Watching English Movie. . .

The researcher analyzed the data by using Descriptive Statistic and Inferential Statistic.

1. Descriptive Statistic

According to Sugiyono (2012) descriptive statistics were used to analyze the data in ways that describe or depict collected data as it is without intending to apply to the general conclusions or generalizations. The use of descriptive statistic in this case is to answer the problems 1 and 2 by using a frequency Tabulation formula, with the following steps:

a. Range (RT)

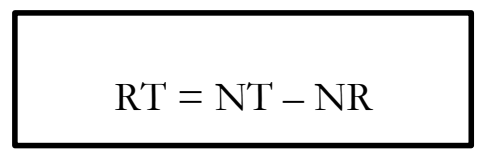

Where;

NT = Higher Score

$\mathrm{NR}=$ Lower Score

b. Quantities of Class Interval (KI)

$$
\mathrm{KI}=1+(3,3) \log \mathrm{n}
$$

Where $\mathrm{n}=$ the number of data

c. Class Length Interval (P)

$$
\mathrm{P}=\frac{\mathrm{RT}}{\mathrm{KI}}
$$

Where;

$\mathrm{RT}=$ Range

$\mathrm{KI}=$ Quantities of Class Interval

d. Mean

$$
\overline{\mathrm{X}}=\frac{\sum \mathrm{n}}{\mathrm{n}}
$$

Where;

$\sum \mathrm{n}=$ total score of data

$\mathrm{n}=$ the number of data

e. Std. Deviation

$$
\mathrm{SD}=\mathrm{i} \frac{\sqrt{\left(\sum \mathrm{fd}^{2}\right)}}{\mathrm{N}}-\frac{\left(\sum \mathrm{fd}\right)^{2}}{\mathrm{~N}}
$$




\section{f. Categorization}

Table 3. Standard of Classification

\begin{tabular}{|c|c|c|}
\hline Variable & Category & Criteria \\
\hline \multirow{3}{*}{$\begin{array}{c}\text { Habit } \\
\& \\
\text { Vocabulary Mastery }\end{array}$} & Low & $\mathrm{X}<$ Mean- ISD \\
\hline & Moderate & $\begin{array}{c}\text { Mean- ISD s/d Mean }+ \\
\text { ISD }\end{array}$ \\
\hline & High & $\mathrm{X}>$ Mean + ISD \\
\hline
\end{tabular}

2. Inferential Statistic

According to Sugiyono (2012) inferential statistics, (often also called inductive statistics or statistical probability), is a technique used to analyze the data sample and the results are applied to the population. The statistics are used to prove the hypothesis by using Pearson product moment correlation. The computer program namely Statistical Packages for Social Sciences (SPSS) Release 16.0. is utilized to process the data.

\section{FINDINGS AND DISCUSSION}

\section{The Findings of Preliminary Research}

a. Student's Habit

Based on the analysis of data by using Frequency Tabulation Formula showed that from 34 students of second year SMAN 1 Anggeraja, 7 students in low category of habit with percentage 20,5\%, 18 students in moderate category of habit with percentage 52,9\%, and 9 students in high category of habit with percentage 26,4\%. The level Student' Habit in Watching English movie of second Tear of SMAN 1 Anggeraja was moderate with frequency of 18 and percentage $52,9 \%$.

Categorization of Students' Habit of Second Year of SMAN 1 Anggeraja

\begin{tabular}{|c|c|c|c|c|}
\hline Variable & Categories & Criteria & Frequency & Percentage \\
\hline \multirow{3}{*}{ Students' Habit } & Low & $\mathrm{X}<26,08$ & 7 & $20,5 \%$ \\
\cline { 2 - 5 } & Moderate & $26,08-35,44$ & 18 & $52,9 \%$ \\
\cline { 2 - 5 } & High & $\mathrm{X}>35,44$ & 9 & $26,4 \%$ \\
\hline \multirow{2}{*}{ Total } & 34 & $100 \%$ \\
\hline
\end{tabular}

b. Students' Vocabulary Mastery

Based on the analysis of data by using Frequency Tabulations Formula showed that from 34 students of second year of SMAN 1 anggeraja, 5 students in low category of vocabulary mastery with percentage 14,7\%, 18 students in moderate category of vocabulary mastery with percentage $52,9 \%$, and 11 students in high category of vocabulary mastery with percentage 32,3\%. The level of Students' Vocabulary Mastery of second Year of SMAN 1 
Dahniar \& Masyhud Zainuddin, The Correlation Between Student's Habit in Watching English Movie. . .

Anggerja was moderate with frequency of 18 and the percentage $52,9 \%$.

\section{Categorization of Students' Vocabulary Mastery of Second Year} of SMAN 1 Anggeraja

\begin{tabular}{|c|c|c|c|c|}
\hline Variable & Categories & Criteria & Frequency & Percentage \\
\hline \multirow{2}{*}{$\begin{array}{c}\text { Students' } \\
\text { Vocabulary } \\
\text { Mastery }\end{array}$} & Low & $\mathrm{X}<66,67$ & 5 & $14,7 \%$ \\
\cline { 2 - 5 } & Moderate & $66,67-80,97$ & 18 & $52,9 \%$ \\
\cline { 2 - 5 } & High & $\mathrm{X}>80,97$ & 11 & $32,3 \%$ \\
\hline & \multicolumn{2}{|c|}{ Total } & 34 & $100 \%$ \\
\hline
\end{tabular}

c. Inferential Analysis

Based on the result of analysis product moment correlation test by using the computer program namely Statistical Packages for Social Sciences (SPSS) Release 16.0 showed $\mathrm{r}_{\mathrm{xy}}=$ 0.766 and $p=0.001$. This shows that there was a significant correlation between Students' Habit in Watching English Movie and Vocabulary Mastery as $\mathrm{p}<0.01$ can be explained by $\left(\mathrm{r}_{\mathrm{xy}}=0.766 ; \mathrm{sig}=0.001<\ldots 0.01\right)$. It could be concluded that the hypothesis has been proven, there is a significant correlation between Students' Habit in Watching English Movie and Vocabulary Mastery at the Second Year of SMAN 1 Anggeraja. It means that, the higher students' habit in watching English movie, the higher students' vocabulary mastery.

\section{Correlation between Students' Habit in Watching English Movie and Vocabulary Mastery at the Second Year of SMAN 1 Anggeraja}

\section{Correlations}

\begin{tabular}{|ll|r|r|}
\hline & & Habit & Vocabulary Mastery \\
\hline & Pearson Correlation & 1 & $.766^{* *}$ \\
& Sig. (2-tailed) & & .000 \\
& $\mathrm{~N}$ & 34 & 34 \\
\hline Mocabulary & Pearson Correlation & $.766^{* *}$ & 1 \\
Mastery & Sig. (2-tailed) & .000 & 34 \\
& $\mathrm{~N}$ & 34 & \\
\hline
\end{tabular}

**. Correlation is significant at the 0.01 level (2-tailed).

\section{Notes;}

Pearson Correlation : the score of coefficient between variables

Sig. (2-tailed) : the significant test of coefficient correlation

$\mathrm{N} \quad$ : the number of sample 


\section{E. CONCLUSION}

After getting the data which has been analyzed on the previous research, the researcher concludes about correlation between students' habit and vocabulary mastery in watching English movie at the second year of SMAN 1 Anggeraja in Academic Year of 2015/2016.

1. Based on the analysis of data about habit in which level of habit is divided into three categories. High habit is $26.4 \%$ with frequency of 7 students, moderate habit is $52,9 \%$ with frequency of 18 students, low habit is $26,4 \%$ with frequency of 9 students. It can be concluded that the level of Students' Habit in Watching English Movie at the Second Year of SMAN 1 Anggeraja is Moderate.

2. Based on the analysis of data about vocabulary mastery in which the level of vocabulary mastery is divided into three categories. High vocabulary mastery is 32,3\% with frequency of 11 students, moderate vocabulary mastery is 52,9\% with frequency of 18 students, low vocabulary mastery is $14,7 \%$ with frequency of 5 students. It can be concluded that the level of Students' Vocabulary Mastery at the Second Year of SMAN 1 Anggeraja is Moderate.

3. According to the data which has been analyzed from the previous chapter, the researcher can conclude that null hypothesis ( $\mathrm{Ho}$ ) is rejected. Based on the results of analysis product moment correlation test by using the computer program namely Statistical Packages for Social Sciences (SPSS) Release 16.0 showed $\mathrm{r}_{\mathrm{xy}}=0.766$ and $\mathrm{p}=0.001$. This showed that there was a significant correlation between Students' Habit in Watching English Movie and Vocabulary Mastery as $\mathrm{p}<0,01$ can be explained by $\left(\mathrm{r}_{\mathrm{xy}}=0.766\right.$; sig $\left.=0,001<\_, 01\right)$. It could be concluded that the hypothesis has been proven, there is a significant Correlation between Students' Habit in Watching English Movie and Vocabulary Mastery at the Second Year of SMAN 1 Anggeraja. It means that, the higher students' habit in watching English movie, the higher students' vocabulary mastery.

\section{F. WEAKNESS}

1. The film is available is not always in accordance with the needs and desired learning objectives, unless the film was designed and manufactured specifically for their own needs.

2. At the time the film was shown, the images move on so that not all students are able to follow the information to be conveyed through the film.

3. Procurement film and video generally require expensive and a lot of time.

\section{G. SUGGESTION}

1. For teachers

a. Teachers have to be selective on choosing a suitable method in teaching and learning process. Teachers have to know what students need in teaching and 
Dahniar \& Masyhud Zainuddin, The Correlation Between Student's Habit in Watching English Movie. . .

learning process, so that it makes students feel comfort during teaching and learning process.

b. The use of media cannot be separated from teaching and learning process. The use of movie is very helpful for teachers during teaching and learning process because it can make students more interested to the material and make students learn happily.

c. The researcher hopes that teachers may create an interactive teaching and learning process in order to make students more active in giving respond to the material.

2. For students

a. The researcher hopes that Students study more and respond in teaching and learning process.

b. The researcher hopes that Students more interested in English lesson.

3. For Researcher

It is suggested to other researcher to complete this research by conducting any other researcher on watching English movie. Based on the explanation above the writer would like to suggest other researcher, that the result of the study can be used as additional reference for further research with different sample and occasions.

\section{REFERENCES}

Arikunto, Suharsimi. Prosedur Penelitian Suatu Pendekatan Praktik, Jakarta: Rineka Cipta. 2013. Andrews. The American Journal of Psychology, Champaign: University of Illinois Press. 1903.

Clark, Herbert H. Psychology and Language: An Introduction to Psycholinguistics. Washington, D.C.: Harcourt Brace Jovanovich, Inc. 1970.

Covey, Stephen R. The Seven Habits of Highly Effective People. London, Simon and Schuster Ltd. 1997.

Danim Sudarwan. Media Komunikasi Pendidikan. Jakarta: Bumi Aksara. 1995.

Gaims Ruth and Redman Stuard. Working With Words: A Guide to Teaching and Learning Vocabulary. New York: Cambridge University Press. 2003.

Gay. Educational research: Competencies for analysis and application (2nd edition.). Columbus, $\mathrm{OH}$ :

Charles E. Merrill Publishing Company.1981.

Good, David. How to improve your vocabulary. 2000. Retrieved on $23^{\text {rd }}$ June 2009 from http://www.wordhacker.com/en/article/howtoimprove vocabulary.htm.

Good. The Dictionary of Education. New York: Garhwali Bok Company. 1973. Habit. Accessed on 14 ${ }^{\text {th }}$ May 2015. http://www.suite101.com.

Harmer, Jeremy. The Practice of English Language Teaching, Malaysia: Pearson, ${ }^{\text {rd }}$ Edition.1991. Brown and Hatch. Vocabulary Semantics and Language. Cambridge University Press, California. 
1995.

Hikmah Nurul. Develoving Students' Vocabulary Using Dora the Explorer Movie. Thesis IAIN Walisongo Semarang. 2009.

Hornby. Oxford Advanced Learners Dictionary of Current English. New York. 1995.

Karim. Stimulating the Students' to Speaking through Problem Solving Activities in the Classroom Interaction (THESIS). Unpublished Thesis Makassar. IKIP Ujung Pandang. 2000.

Hornby. Oxford Learner's Pocket Dictionary. New York: Oxford University Press.1995.

Rahman Arif. Correlation between Frequency of Watching English Movies and Vocabulary Mastery of the Second Grade Students of MAN 1 Semarang in the Academic Year of 2011/2012. Thesis IAIN Walisongo Semarang. 2012.

Safi'i Ahmad. Korelasi antara Kebiasaan Menonton Film Berbahasa Inggris dan Pengusaan Kosa Kata Siswa di SMKN 1 Salatiga. Thesis STAIN Salatiga. 2013.

Saraswathi V. English Language Teaching Principle and Practice. Chennai: Orient Longman Private Limited Press. 2004.

Schail, William. Seven Days to Faster Reading. New York: Paper Black Library. 1967.

S Eliab, Bong. "Film Principle", http://eliab.tripod.com/films, accessed on $15^{\text {th }}$ May 2015.

Sugiyono. Metode Penelitian Kuantitatif Kualitatif dan R\&B. Bandung: Alfabeta.2012.

Thomas, Diana. Flexible Learning Strategies in Higher and Further Education (Cassell Education). London: Casseell. 1995.

Twyman. The Function of Film, http://www.twyman-whitney.com/film/functions reviewing, accessed on $15^{\text {th }}$ May 2015.

Wallace J. Michael. Teaching Vocabulary. New York. Oxford University Press. 1994.

Webster, Webster's Third New International Dictionary and Seven Language Dictionary: Three Volumes. Encyclopedia Britannica. 1983.

Wikipedia. "Habit”, https://en.wikipedia.org/wiki/Habit accessed on 14 May 2015.

Wikipedia. "Movie", http://en.wikipedia.org/wiki/Film genre accessed on $15^{\text {th }}$ May 2015. 